\title{
Hubungan panjang telapak kaki dengan tinggi badan untuk identifikasi forensik
}

\author{
${ }^{1}$ Jinov Tomuka \\ ${ }^{2}$ James Siwu \\ ${ }^{2}$ Johannis F. Mallo
}

${ }^{1}$ Kandidat Skripsi Fakultas Kedokteran Universitas Sam Ratulangi Manado
${ }^{2}$ Bagian Ilmu Forensik dan Medikolegal Fakultas Kedokteran
Universitas Sam Ratulangi Manado
Email: jinovtomuka296@gmail.com

\begin{abstract}
Forensic identification is a method to provide assistance for investigators in personal identification which is very important in court. Forensic anthropology is a branch of physical anthropology that assists medical forensic practice by focusing on individual biological profile asessment and reconstruction by using anthropometry. Body height is a parameter of human growth and health. In forensic anthropology, height is also a main biological profile in identification. Foot length can be used to determine body height since there is a correlation between these two biological profiles. This study aimed to obtain the relationship between foot length and body height. This was a quantitative analytical study. Subjects were students of batch 2012 of Faculty of Medicine, University of Sam Ratulangi Manado, aged $>21$ years. The results showed that there was a positive correlation $(\mathrm{r}=0.539)$ with a probablity value of 0.000 . Conclusion: There was a significant positive correlation between foot length and height.
\end{abstract}

Keywords: forensic identification, forensic anthropology, anthropometry

\begin{abstract}
Abstrak: Identifikasi forensik merupakan upaya yang bertujuan membantu penyidik dalam menentukan identitas seseorang yang sangat penting dalam peradilan. Sebagai salah satu cabang antropologi khususnya antropologi ragawi, peran antropologi forensik didasarkan pada kemampuan pemeriksaan antropologis untuk menilai dan merekonstruksi gambaran biologis individu manusia; salah satu cara identifikasi ialah dengan antropometri. Tinggi badan merupakan suatu parameter dari pertumbuhan dan kesehatan manusia. Tinggi badan juga merupakan salah satu ciri utama untuk proses indentifikasi. Bagian tubuh yang dapat menunjang pengukuran tinggi badan yaitu panjang telapak kaki karena tinggi badan dan panjang telapak kaki mempunyai hubungan yang berbanding lurus. Penelitian ini bertujuan untuk mengetahui hubungan antara panjang telapak kaki dan tinggi badan. Jenis penelitian ini kuantitatif analitik. Subyek penelitian ialah mahasiswa Fakultas Kedokteran Universitas Sam Ratulangi Manado angkatan 2012 yang berusia >21 tahun. Penelitian ini dilakukan di Manado pada bulan Oktober-Desember 2015. Hasil penelitian mendapatkan korelasi positif antara kedua variabel dengan nilai koefisien $r=0,539$ yang menunjukkan bahwa kedua variabel berhubungan positif. Terdapat hubungan bermakna antar kedua variabel penelitian dengan nilai $\mathrm{P}=0,000$. Simpulan: Terdapat hubungan positif bermakna antara panjang telapak kaki dan tingggi badan.
\end{abstract}

Kata kunci: identifikasi forensik, antropologi forensik, antropometri

Identifikasi forensik merupakan upaya yang dilakukan dengan tujuan membantu penyidik untuk menentukan identitas seseorang. Peran ilmu kedokteran forensik 
dalam identifikasi terutama pada jenazah tidak dikenal. Identitas seseorang dapat dipastikan bila paling sedikit dua metode yang digunakan memberikan hasil yang tidak meragukan. ${ }^{1}$

Peran antropologi forensik menjadi salah satu cabang antropologi khususnya antropologi ragawi dalam menunjang pelayanan kedokteran forensik didasarkan pada kemampuan pemeriksaan antropologis untuk menilai dan merekonstruksi gambaran biologis individu manusia dengan rentang waktu mencakup manusia dari masa lampau hingga sekarang. ${ }^{1}$

Metode dalam antropologi forensik yaitu dapat digunakan untuk identifikasi ialah antropometri yaitu dengan cara mengukur bagian-bagian tubuh. Pengukuran antropometri berdasarkan tinggi badan, panjang dan lebar kepala, sidik jari, bentuk hidung, telinga, dagu, warna kulit, warna rambut, tanda pada tubuh, serta DNA. $^{2}$

Tinggi badan merupakan salah satu parameter dari pertumbuhan dan kesehatan manusia. Tinggi badan juga merupakan salah satu ciri utama untuk proses identifikasi dan merupakan salah satu profil biologis utama dalam antropologi forensik. ${ }^{3}$

\section{METODE PENELITIAN}

Jenis penelitian ini kuantitatif analitik. Penelitian ini dilakukan di Manado pada bulan Oktober-Desember 2015 terhadap mahasiswa Fakultas Kedokteran angkatan 2012 Universitas Sam Ratulangi yang berusia $>21$ tahun.

\section{HASIL PENELITIAN DAN BAHASAN}

Selain pengukuran tinggi badan dan panjang telapak kaki, juga diperlukan identitas diri berupa usia dan jenis kelamin.

Tabel 1. Distribusi subyek berdasarkan usia

\begin{tabular}{ccccc}
\hline Valid & Frequency & $\%$ & $\begin{array}{c}\text { Valid } \\
\text { Percent }\end{array}$ & $\begin{array}{c}\text { Cumulative } \\
\text { Percent }\end{array}$ \\
\hline 21 & 38 & 97,4 & 97,4 & 97,4 \\
22 & 1 & 2,6 & 2,6 & 100 \\
Total & 39 & 100 & 100 & \\
\hline
\end{tabular}

Tabel 1 menunjukkan usia dari 39 subyek yang diambil dengan usia $>21$ tahun. Frekuensi terbanyak untuk laki-laki dan perempuan ialah usia 21 tahun dengan jumlah 38 orang sedangkan usia 22 tahun hanya berjumlah 1 orang.

Tabel 2 memperlihatkan distribusi frekuensi subyek menurut jenis kelamin. Subyek dengan jenis kelamin laki-laki memiliki jumlah terbanyak yaitu 27 orang dibanding perempuan 12 orang.

Tabel 2. Distribusi subyek berdasarkan jenis kelamin

\begin{tabular}{c|c|c|c|c}
\hline Valid & Frequency & Percent & $\begin{array}{l}\text { Valid } \\
\text { Percent }\end{array}$ & $\begin{array}{l}\text { Cumulative } \\
\text { Percent }\end{array}$ \\
\hline L & 27 & 69,2 & 69,2 & 69,2 \\
P & 12 & 30,8 & 30,8 & 100 \\
Total & 39 & 100 & 100 & \\
\hline \multicolumn{5}{c}{ L = Laki-laki } \\
P = Perempuan
\end{tabular}

Tabel 3 menjelaskan minimum, maksimum, rerata dan standar deviasi dari usia subyek yaitu minimum 21 tahun dan maksimum 22 tahun dengan rerata 21,02 dan standar deviasi 0,160.

Tabel 3. Minimum, maksimum, rerata, dan standar deviasi dari usia subyek

\begin{tabular}{llllll}
\hline & $\mathrm{N}$ & Min & Maks & Rerata & SD \\
\hline Usia & 39 & 21 & 22 & 21,02 &, 160 \\
N & 39 & & & & \\
\hline
\end{tabular}

$\mathrm{N} \quad=$ Jumlah subyek penelitian

Min = Nilai terendah dalam variabel

Maks = Nilai tertinggi dalam variabel

$\mathrm{SD} \quad=$ Standar Deviasi

Tabel 4 menunjukkan nilai rerata, minimum, maksimum dan standar deviasi untuk pengukuran tinggi badan laki-laki. Dari 27 orang laki-laki didapatkan nilai rerata tinggi badan $165,2 \mathrm{~cm}$, nilai minimum 150,7 cm, nilai maksimum 178,2 $\mathrm{cm}$, dengan standar deviasi 6,85.

Tabel 4 juga menunjukkan nilai rerata, minimum, maksimum, dan standar deviasi dari pengukuran panjang telapak kaki lakilaki. Dari 27 orang laki-laki didapatkan nilai rerata panjang telapak kaki $24,64 \mathrm{~cm}$, nilai minimum 22,50 cm, nilai maksimum 
29,20 cm, dengan standar deviasi 1,50.

Tabel 4. Nilai rerata, minimum, maksimum dan standar deviasi untuk pengukuran tinggi badan dan panjang telapak kaki subyek lakilaki

\begin{tabular}{l|l|l|l|l|l}
\hline & N & Min & Max & Rerata & SD \\
\hline TB & 27 & 150,7 & 178,2 & 165,3 & 6,85 \\
PTK & 27 & 22,5 & 29,2 & 24,64 & 1,50 \\
N & 27 & & & & \\
\hline
\end{tabular}

$\mathrm{TB}=$ Tinggi badan

PTK = Panjang telapak kaki

$\mathrm{N} \quad=$ Jumlah subyek penelitian

Min = Nilai terendah dalam variabel

Maks = Nilai tertinggi dalam variabel

$\mathrm{SD} \quad=$ Standar Deviasi

Tabel 5 menunjukkan nilai rerata, minimum, maksimum, dan standard deviasi dari pengukuran tinggi badan perempuan. Dari 12 orang perempuan didapatkan nilai rerata tinggi badan 155,6 cm, nilai minimum $145 \mathrm{~cm}$, nilai maksimum $166 \mathrm{~cm}$ dengan standar deviasi 5,92.

Tabel 5. Nilai rerata, minimum, maksimum, dan standard deviasi dari pengukuran tinggi badan perempuan

\begin{tabular}{cccccc}
\hline & N & Min & Maks & Rerata & SD \\
\hline TB & 12 & 145 & 166 & 155,6 & 5,92 \\
PTK & 12 & 19,7 & 25 & 22,9 & 1,35 \\
N & 12 & & & & \\
\hline
\end{tabular}

Keterangan:

$\mathrm{N}=$ Jumlah Subyek Penelitian

Min $=$ Nilai terendah dalam variabel

Max $=$ Nilai tertinggi dalam variabel

$\mathrm{SD}=$ Standar Deviasi

Tabel 5 juga menunjukkan nilai rerata, minimum, maksimum, dan standar deviasi dari pengukuran panjang telapak kaki perempuan. Dari 12 orang perempuan didapatkan nilai rerata panjang telapak kaki $22,9 \mathrm{~cm}$, nilai minimum $19,7 \mathrm{~cm}$, nilai maksimum $25 \mathrm{~cm}$, dengan standar deviasi 1,35 .

Hasil kedua tabel diatas menunjukkan bahwa rerata tinggi dan panjang telapak kaki laki-laki lebih dari perempuan. Lakilaki memiliki rerata 165,3 cm $(\mathrm{SD} \pm 6,85)$ sedangkan rerata tinggi badan perempuan
155,6 cm (SD $\pm 5,92)$. Rerata panjang telapak kaki laki-laki 24,64 cm (SD $\pm 1,50)$ sedangkan rerata panjang telapak kaki perempuan 22,9 cm (SD $\pm 1,35)$.

Tabel 6 menunjukkan hasil uji normalitas pengukuran tinggi badan dan panjang telapak kaki dengan perhitungan Shapiro-Wilk. Nilai signifikan tinggi badan 0,929 dan nilai signifikan panjang telapak kaki 0,056 yang berarti terdistribusi normal dimana nilai $\mathrm{p}>0,05$.

Tabel 6. Hasil uji normalitas pengukuran tinggi badan dan panjang telapak kaki dengan perhitungan Shapiro-Wilk.

\begin{tabular}{lccc}
\hline & \multicolumn{3}{c}{ Shapiro-Wilk } \\
\cline { 2 - 4 } & Statistic & df & Sig. \\
\hline TB &, 987 & 39 &, 929 \\
PTK &, 945 & 39 &, 056 \\
\hline
\end{tabular}

TB = Tinggi badan

PTK = Panjang telapak kaki

Tabel 7 menunjukkan hasil korelasi antara panjang telapak kaki dengan tinggi badan dengan nilai $r=0,539$ yang menandakan hubungan yang kuat antara kedua variabel tersebut. Dari hasil korelasi tersebut juga didapatkan nilai p (signifikan) $=0,000$ yang berarti terdapat hubungan bermakna antara kedua variabel tersebut.

Tabel 7. Hasil korelasi antara panjang telapak kaki dengan tinggi badan

\begin{tabular}{l|c|c}
\hline & TK & TB \\
\hline PTK Pearson Correlation & 1 &, $539 * *$ \\
Sig. (2-tailed) & &, 000 \\
N & 39 & 39 \\
TB Pearson Correlation &, $539 * *$ & 1 \\
Sig. (2-tailed) &, 000 & \\
$\mathrm{~N}$ & 39 & 39 \\
\hline
\end{tabular}

Secara keseluruhan, hasil penelitian ini mendapatkan hubungan sangat bermakna antara panjang telapak kaki dan tinggi badan. Hal ini disebabkan penyusun panjang telapak kaki sebagian besar ialah tulang-tulang panjang yang tumbuh dan berkembang bersamaan dengan tulangtulang panjang penyusun tinggi badan. 
Dengan kata lain, jika telapak kaki bertambah panjang, maka tubuh juga bertambah tinggi, begitu juga sebaliknya.

Mahasiswa Fakultas Kedokteran Angkatan 2012 Universitas Sam Ratulangi yang berasal dari bermacam-macam daerah dianggap peneliti sebagai miniatur populasi orang dewasa Indonesia. Hal tersebut mendasari pengambilan subyek menggunakan rumus Slovin dan didapatkan besaran sampel sebanyak 39 sampel.

\section{SIMPULAN}

Dari hasil penelitian dan bahasan dapat disimpulkan bahwa terdapat hubungan bermakna antara kedua panjang telapak kaki dan tinggi badan dengan perbandingan 1:7 baik pada laki-laki maupun perempuan.

\section{DAFTAR PUSTAKA}

1. Peran Antropologi Forensik dalam Kedokteran Forensik. Available from: http://www.vikaasriningrum.com/2009/ 12/peran-antropologi-forensikdalam.html

2. Glinka J. Antropometri \& Antroposkopi (3rd ed). Surabaya: Fisip Universitas Airlangga, 1990.

3. Tinggi badan berdasarkan tulang tibia, humerus, ulna dan radius pada laki-laki dewasa muda. Available from: http://repository.maranatha.edu/8764/3/ 0810216_Chapter1.pdf. 